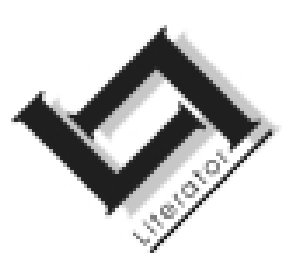

\title{
Het labyrint in de letterkunde: Van de Barok tot het Postmodernisme ${ }^{1}$
}

\author{
Hans Ester \\ Opleiding Algemene Cultuurwetenschap \\ Universiteit van Nijmegen \\ NIJMEGEN \\ E-pos: j.ester@let.kun.nl
}

\section{Abstract}

The labyrinth in literature: From Baroque to Postmodernism

The labyrinth has proved to be an essential symbol of postmodernist literature and the philosophy of our time. This symbol has apparently had the power to bridge the centuries between Ancient Greece and the year 2000. In reality the labyrinth as a geometrical figure has acquired various meanings in the course of time. The history of the labyrinth as symbol shows that the constant elements are as essential as the changes in meaning from the Middle Ages until the present day. Two of the new symbolic elements that accompany the labyrinth on its way through various cultural periods are the garden and the path of life. During the Baroque the labyrinth, for example, represented the synthesis of garden, path and maze. At the end of the twentieth century the labyrinth once more becomes a dominant and significant structure. The labyrinth reflects the inability and perhaps impossibility to find the key to the centre of the world and to discover the truth behind the words we use. On the other hand, the labyrinth suggests that the search for meaning and truth is an aim in itself or even that this search can lead to new forms of wisdom. The labyrinth therefore is an ambivalent and fascinating symbol of our time. Dedalus and Ariadne, however, have not yet brought the salvation we are waiting for.

1 Bij het schrijven van dit artikel heb ik gebruik gemaakt van enkele inzichten uit mijn opstel "Geheime tuinen en gesloten deuren. Over open en verboden ruimtes in tekst en beeld" (Mulder \& Ester, 1996:167-179). 


\section{Het labyrint als brug van de Klassieke Oudheid tot het Postmodernisme?}

Het labyrint als geometrisch patroon en als denkfiguur is in onze tijd alom aanwezig. Dat is een zeer opmerkelijk verschijnsel. Het gaat bij het labyrint om een motief dat in de meeste gevallen verbonden is (of wordt) met gegevens uit de Griekse mythologie. Het labyrint is klaarblijkelijk in staat om een brug tussen de Klassieke Oudheid en het Postmodernisme te slaan. Ik gebruik het woord "brug" en besef dat ik hiermee een beeld gebruik dat een eigen logica bezit die het transport van het labyrint door de eeuwen heen te glad weergeeft en te weinig het proces van verandering problematiseert dat het labyrint onderweg naar onze tijd toe heeft ondergaan. Zoals bekend is, het labyrint geen exclusief Grieks domein, maar een universeel patroon dat ouder is dan de traditie die tot de mythe van het labyrint op Kreta wordt herleid. We kunnen echter niet ontkennen dat het door Daedalus in opdracht van koning Minos gebouwde labyrint van grote betekenis is geweest voor de verwerking van dit literaire motief.

Was het voorspelbaar dat er in de landschappen van Europa opnieuw labyrinten zouden worden geschapen? Een moeilijk te beantwoorden vraag. In ieder geval zien we dat het gebeurt en niet slechts op enkele geïsoleerde plaatsen. Als doolhof in parken en speeltuinen is het labyrint uiteraard nooit helemaal weg geweest (voorbeelden: Hampton Court nabij Londen, diverse graslabyrinten elders in Engeland), maar nu verschijnt het in onze zeer sterk gemechaniseerde wereld onder de eigen mysterieuze, zelfs magische naam, bijvoorbeeld in de grote hal van het Guggenheim Museum Bilbao met het labyrint van Robert Morris. Hierover is in kranten en tijdschriften zeer veel gepubliceerd. Ik noem slechts het artikel "Retrouver son âme là-bas, en suivant les méandres du labyrinthe" (Mascaro, 1998). Is het labyrint als een reactie te beschouwen op een door en door rationeel georganiseerde wereld waaruit de geheimen (maar niet de gevaren) zijn verdwenen, als een poging om de complexiteit van onze ziel via een archaïsche voorstelling voor ogen te roepen? Het zou onjuist zijn om één antwoord op deze vraag te verwachten. Voor een eenduidig antwoord is het verschijnsel in onze tijd zelf te complex en reikt het van een speelse herschepping van het landschap tot de naamgeving van educatieve tijdschriften, bijvoorbeeld: Labyrint. Levensbeschouwing in de basisvorming van het Katholiek Pedagogisch Centrum in 's-Hertogenbosch. Er is in de Verenigde Staten van Amerika onder de inspirerende leiding van Lauren Artress zelfs een waarachtige "Christian Labyrinth Movement" ontstaan die mobiele (verwijderbare) labyrinten in kerken aanbrengt en de gelovigen laat herhalen wat de Middeleeuwse mens uitstekend kende als weg naar Christus. De 
genoemde "Christian Labyrinth Movement" formuleert haar credo met betrekking tot het labyrint als volgt: "[...] the labyrinth is opening a longclosed door into mystical spirituality for those inside and outside organized Christianity [...]" (bron: Los Angeles Times, ongedateerd). Het is de vraag of deze formulering meer te zeggen heeft dan dat de aanhangers van de Beweging het labyrint voor hun godsdienstige beleving zeer serieus nemen. Terloops zij opgemerkt dat de onderscheiding van labyrint en doolhof door het taalgebruik niet altijd eenvoudig is. Sommige onderzoekers beweren dat er tot de Renaissance slechts labyrinten bestonden, meetkundige structuren die via vele omwegen, maar zonder keuzemogelijkheden, naar het centrum leiden. Bij het doolhof worden de bezoeker juist vele verwarrende keuzemogelijkheden geboden. Vooral in het taalgebruik van de twintigste eeuw zijn beide begrippen met elkaar verward geraakt.

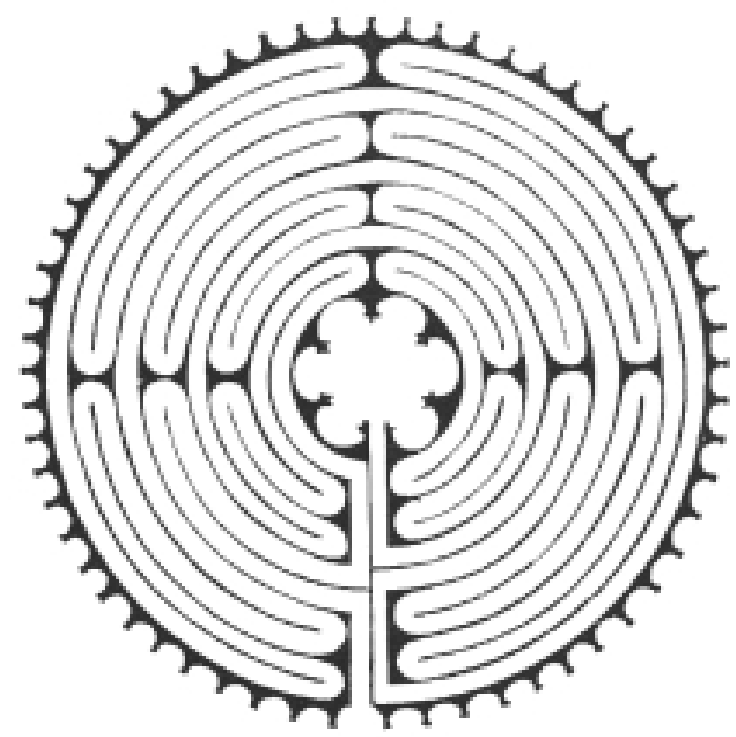

Plattegrond van het labyrint van de kathedraal van Chartres (Attali, 1996:no. 36)

\section{Van de Minotaurus naar de twijfel aan de waarheid}

Het labyrint is een oud symbool, gebaseerd op een oud verhaal. Het labyrint nu is deel van de kritische bezinning op het verleden. Het labyrint is, niet zonder een belangrijke gedaanteverwisseling te hebben ondergaan en nochtans zichzelf te zijn gebleven, getransponeerd van het eiland Kreta naar de wereld van het Postmodernisme. Het labyrint heeft zijn atavistische karakter bewaard en is daarbij springlevend in betekenis gebleven. Dat is het meest opmerkelijke aan het labyrint zoals het thans in de beeldende kunst en in de literatuur functioneert. De meest gezaghebbende studie over het labyrint is: Hermann Kern, Labyrinthe. Erscheinungsformen und Deutungen. 5000 Jahre Gegenwart eines Ur- 
bilds uit 1982 (vgl. Kern, 1999). De titel van Kern's magistrale overzicht geeft de spanningsboog tussen het archaïsche en het actuele duidelijk aan. Kern's boek is geboren uit een catalogus die hij bij een tentoonstelling in opdracht van de stad Milaan samenstelde.

Cruciaal is de vraag naar de wijze van herwaardering van het labyrint in de cultuur anno 2000. Op welke manieren is het labyrint als sleutel tot het postmoderne bewustzijn opnieuw met betekenis beladen? Hoe verhoudt zich de zoektocht naar het midden van het labyrint met de Minotaurus met de ontkenning van de mogelijkheid om een absolute waarheid te vinden, zoals we deze ontkenning uit het Postmodernisme kennen? Is het niet curieus dat juist in het Postmodernisme het labyrint gelegitimeerd wordt, zonder dat er sprake is van een waarheidspretentie? Of zou er sprake kunnen zijn van een soort "deel-waarheid" van dat labyrint, en als gevolg daarvan ook van het Postmodernisme?

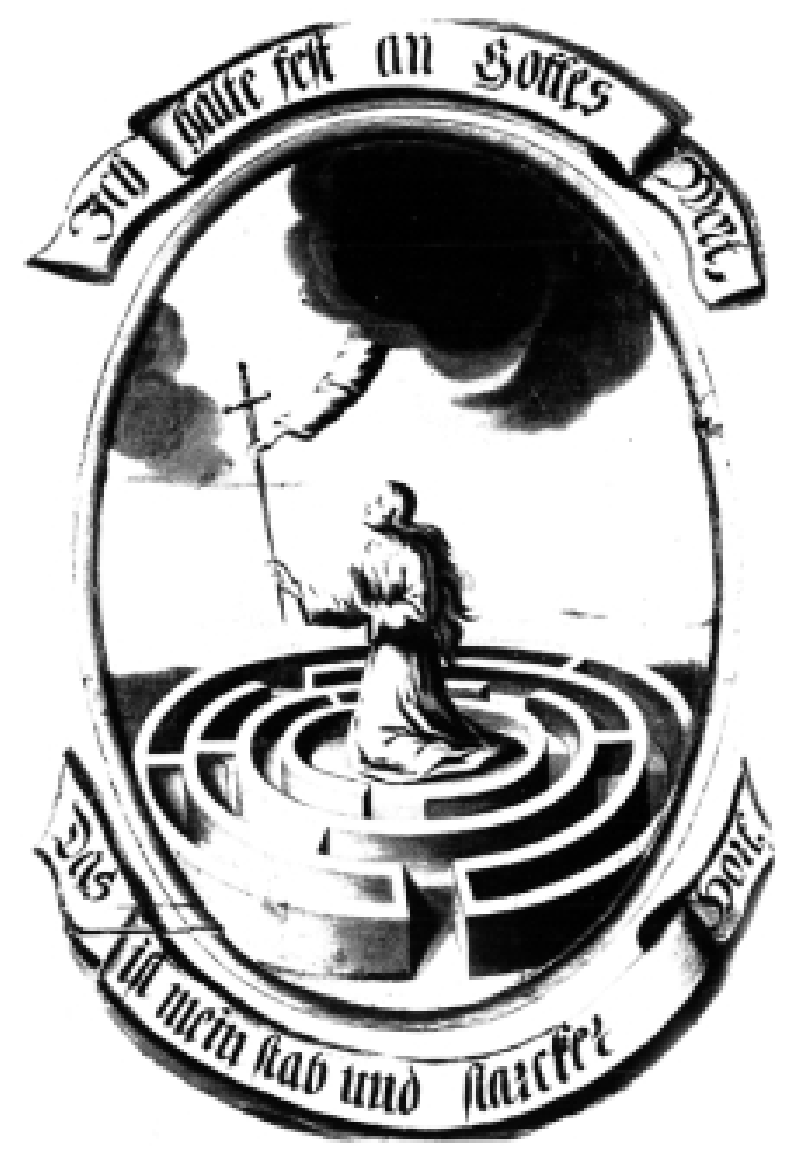

Labyrint-embleem in de slotkerk van Retten/ Remstal, Duitsland (Kern, 1999:302)

De postmoderne mens - om het een beetje pathetisch te formuleren gaat op een bepaalde manier om met de traditie waarvan hij zich niet kan losmaken. Het Postmodernisme is wezenlijk iets anders dan de radicale ontworteling van tradities die Friedrich Nietzsche bepleitte. Ook 
al bevat de traditie geen verplichtende verkeersborden: richting waarheid, zij dient als kader waarbinnen gedacht en gehandeld (eventueel: gemanipuleerd) wordt, om erkenning te krijgen. Zonder het bewustzijn van de traditie, valt de kritische afstand ten opzichte van de denkkaders van die traditie weg. Maar hoe staat het labyrint ten opzichte van dit denken dat de eigen vooroordelen en slagschaduwen in het denken betrekt? Om hier enig zicht op te krijgen, is het noodzakelijk om het labyrint als ruimtelijk levensconcept in verband te brengen met andere voorstellingen die het leven eveneens in een combinatie van tijd en ruimte begrijpen en daarmee ook van een bepaalde zin voorzien. Ik doel hierbij op de zeer algemene voorstelling van het leven als reis, als levensreis, onderweg door tijd en ruimte, naar een eindbestemming, de tuin, het paradijs, of naar een horizon die als eindpunt uiteraard altijd verschuift en daarom nooit te bereiken zal zijn.

\section{Het leven als reis, onderweg naar de tuin}

De voorstelling van het leven als reis is in ieder geval een in de mondiale tradities zeer dominante metafoor voor het geheel van het menselijk bestaan vanaf de geboorte tot aan de dood geweest. In de traditie van de Europese cultuur, hoogstwaarschijnlijk van een universele cultuur, zijn behalve het leven als reis de voorstelling van de toegangspoort en de veelal ommuurde tuin van het uiterste belang als beelden die zich tegen alle veranderingen in (of met alle veranderingen mee) weten te handhaven. Een typologie van de tuin vanuit de spirituele groei van de mens geeft Wolfgang Teichert in zijn boek Gärten. Paradiesische Kulturen uit 1986. Teichert ziet eveneens het verband van labyrint en tuin en beschouwt het labyrint als een heilige ruimte waarvan het centrum een ommekeer mogelijk maakt. Teichert psychologiseert het labyrint en gebruikt daarbij de opvattingen van Jung (Teichert, 1986:84). Wanneer we de ideeën van Jung volgen, gaat het hierbij om de verbeelding van diep in de mens sluimerende angsten en verlangens vanuit de verankering van het menselijk leven in een psychisch substraat dat de ervaringen van onze voorouders vasthoudt. De Franse cultuurfilosoof Jacques Attali sluit zich in zijn verhandeling Chemins de sagesse. Traité du labyrinthe (1996) bij de opvattingen van Jung aan en spant een boog terug naar de nomadische tijden van de mensheid. Volgens Jung worden de beelden (of eerder: impulsen) van het collectieve onderbewuste tot leven gewekt op het moment dat ons psychisch evenwicht verstoord dreigt te raken. De beelden - die een deskundige uitleg nodig hebben dringen zich onder meer in onze dromen aan ons op en doen een appel op ons om in te grijpen. We kunnen behalve naar ons collectief onderbewuste ook naar gecanoniseerde, normatieve teksten verwijzen die als richtsnoer voor ons denken fungeerden en wellicht nog steeds 
fungeren. Het gaat dan om culturele tradities eerder dan om psychische substraten. De Europese voorstellingen met betrekking tot de dimensies van het leven hebben hun wortels voor een aanzienlijk deel in de Bijbel waarin het leven op veel plaatsen met behulp van ruimtelijke voorstellingen wordt omschreven. De beelden van de Bijbel hebben zelf tot die ruimtelijke voorstellingen bijgedragen of sloten wellicht op hun beurt aan op een reeds bestaand psychisch gegeven. Het centrale uitgangspunt hierbij is dat de tijd in ruimte wordt uitgedrukt. Het leven is een tocht, een reis, een weg die de mens aflegt. Het woord weg neemt in concordanties van de Bijbel meer dan twee dichtbedrukte bladzijden in beslag. In het boek Exodus wordt gesproken over "de rechte weg" van de mens en in Richteren is sprake van "de weg des Heren". In het evangelie volgens Mattheus, hoofdstuk 7, horen we over "de smalle weg die ten leven leidt". Christus is zelf die weg. Welk opvoedkundig gesprek anno 2001 kan volstaan zonder de visualisering van het leven via een pad of een weg? De smalle weg uit de Bijbel ligt ten grondslag aan de allegorische voorstelling van het leven als keuze tussen de brede en de smalle weg, zoals deze voorstelling op kunstzinnig onbeholpen, maar zeer effectieve wijze is vastgelegd door een Piëtistisch geörienteerde vrouw uit het Zwaben van de vorige eeuw. Op deze, ook in Zuid-Afrika wijd en zijd verbreide tekening is te zien dat de toegang tot de smalle weg een poort is, terwijl de brede weg geen enkele belemmering van hek, poort of deur kent en de zondige mens meteen de speelzaal of het bordeel binnenhaalt. De smalle weg is een kronkelweg (met labyrintische trekken), onverhard, met risico's maar ook met de lafenis van een waterbron. Het einddoel van de brede weg is een berg met een helse krater waarin de zondigen verdwijnen na een laatste blik op de "zondagstrein" te hebben geworpen. De smalle weg leidt naar de gouden stad met het gouden Lam, het hemelse Jeruzalem. De zondige stad is hier overwonnen in de hemelse veste.

\section{De tuin en het paradijs}

Een van de meest penetrante en indrukwekkende literaire voorstellingen van het leven als moeizame tocht langs een weg die op grond van alle ermee verbonden moeiten tot de allegorische voorstelling van de smalle weg wordt, is John Bunyan's The pilgrim's progress from this world to that which is to come. Delivered under the similitude of a dream, dat voor het eerst werd gepubliceerd in 1678. De Keulse theoloog Udo Tworuschka behandelt Bunyan in het grote hoofdstuk "Reisebilder des Lebens" van zijn boek Sucher. Pilger. Himmelsstürmer uit 1991. Bij Bunyan vinden we niet alleen de voorstelling van het leven als weg, maar ook van de wereld als labyrint en we treffen bij hem het beeld van de tuin als hernieuwd paradijs aan. Het onderweg zijn, het "nomadische" 
om met Attali te spreken, wordt duidelijk gesteld boven het gevestigd zijn. Ook Bunyan staat in een lange traditie. De vallei waarover de gids in The pilgrim's progress spreekt, is het paradijs in herstelde staat, terwijl het beeld van het leven als pelgrimstocht impliciet en expliciet het verdwalen, het afdwalen van het rechte pad omvat.

Het beeld van de omsloten tuin neemt in de christelijke iconografie een belangrijke plaats in. De ethymologie van tuin is indicatief voor de diepe betekenis van woord en beeld. Het Duitse woord Zaun en het Engelse en Zuid-Afrikaanse woord town zijn tot dezelfde wortel te herleiden als het Nederlandse woord. De grondbetekenis is: een ruimte, omringd door muren of andere afscheidingen waardoor de vrede en de harmonie van de mensen in die tuin gegarandeerd zijn. De garant van het harmonische is de vredige ruimte zelf geworden. Het woord paradijs is qua ethymologie met tuin vergelijkbaar. Tijdens de Middeleeuwen is de verkondiging aan Maria op veel afbeeldingen in een gesloten, ommuurde tuin gesitueerd. In deze hortus conclusus zien we planten, bloemen en een fontein waaruit water vloeit. Dit is de nieuwe Tuin van Eden waarin de fontein aan de rivieren herinnert die door het oorspronkelijke Eden stroomden en die tuin van het benodigde water voorzagen. Maria is de nieuwe Eva. Zij herstelt mede de orde die door het plukken en eten van de appel van de boom der kennis van goed en kwaad verstoord was geraakt.

\section{Labyrint en tuin}

Labyrint en tuin komen in de christelijke traditie duidelijk bij elkaar. In het midden van de Tuin van Eden stonden volgens het verhaal in Genesis twee bomen: de levensboom en de boom der kennis van goed en kwaad. De levensboom is te zien op een kopergravure die ter illustratie van een gedicht van Jacob Cats dient. De gravure is tevens een illustratie van de Bijbeltekst 2 Thimotheus 3, vers 6 waarin voor zondige begeerten wordt gewaarschuwd en zij is een wegwijzer om veilig door het labyrint van de verliefdheden binnen de beschermende haven van het huwelijk te geraken. We zien op de kopergravure verschillende liefdesparen die zich in een labyrint van heggen bewegen die tot heuphoogte reiken. Een vrouw met een tuiltje bloemen in de hand betreedt het labyrint, daartoe met behulp van de Ariadnedraad geleid door Amor. Amor wijst in de richting van een man die zich zonder gezellin in het labyrint bevindt. In het midden van deze voorstelling is een feestelijk gezelschap bijeen. In een prieel onder een boom wordt het huwelijksfeest gevierd. Vier medaillons in de hoeken van de gravure completteren de betekenis. Linksboven zien we een paar bij een wegwijzer voor een labyrint staan, linksonder twee kalveren, rechtsboven Amor op een kalf 
(in beide gevallen gaat het om toespelingen op de kalverenliefde) en rechtsonder tenslotte de hand Gods die met behulp van de draad van Ariadne de weg door het bos wijst. De mens wordt hier opgeroepen om te vluchten voor de begeerten der jeugd en de weg door het labyrint te wagen om uiteindelijk uit te komen bij de plaats van genezing en heil: het huwelijk. Het huwelijk is volgens deze voorstelling een paradijselijk oord, ook het oord van de vruchtbaarheid, een plek waar de boom des levens groeit.

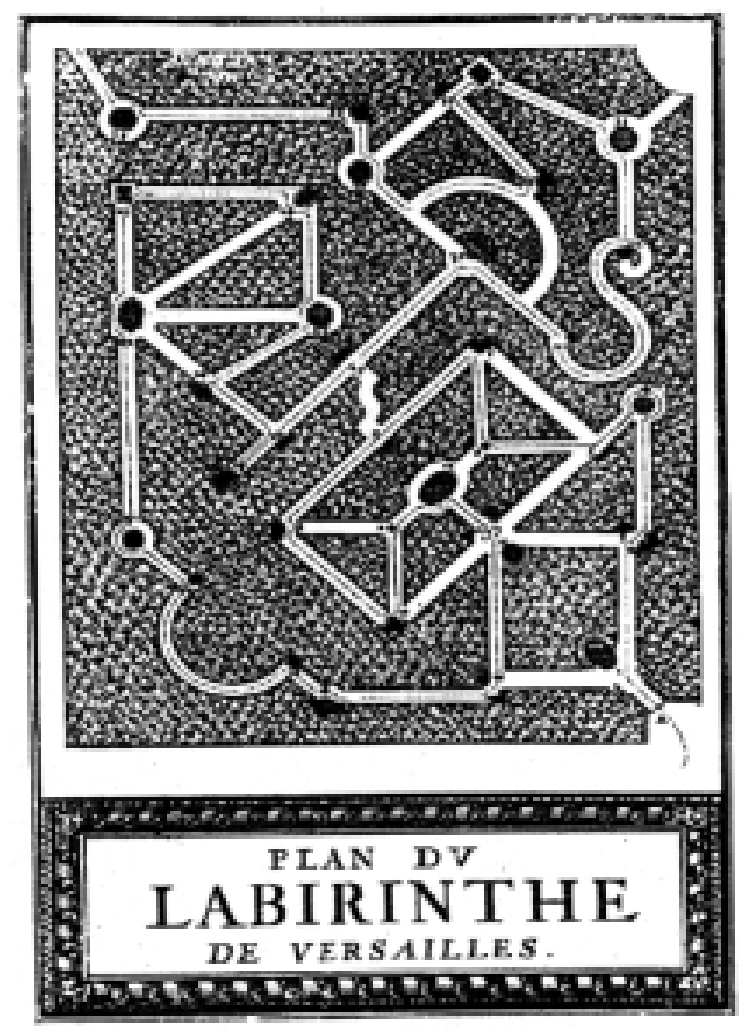

Plattegrond van het labyrint in de beroemde tuinen van Versailles (Attali, 1996 no. 49)

\section{De Barok en het labyrint}

Een der dominante voorstellingen van de Barok is de verbeelding van het menselijk bestaan als labyrint. Tijdens de Middeleeuwen was het verhaal over de Minotaurus in het labyrint van koning Minos op het eiland Kretha en over Theseus, die met behulp van de draad van Ariadne het monster overwon, levend gebleven. Zie bijvoorbeeld het hoofdstuk uit Kern's boek over de "Kirchen-Labyrinthe" (Kern, 1999:206243; met een overzicht van alle kerklabyrinten). De Middeleeuwen interpreteerden de overwinning op de Minotaurus in christelijke zin als een zege van Christus over de duivel in het centrum van het als hel begrepen labyrint. Ook Christus figureert soms in het middelpunt van het labyrint. In dat geval is de af te leggen weg die van de gelovige naar de 
verlosser. In het portaal van menige middeleeuwse kerk is aan de wand een model van een labyrint bevestigd - de kathedraal van Chartres met tevens een groot labyrint in de stenen vloer is hier een illustratief voorbeeld - ter herinnering aan de noodzakelijke levensweg van de mens die het heil deelachtig wil worden en tevens als signatuur van de architect van het bouwwerk die zich daarmee in de traditie van de grote bouwmeester Daidalos (van het labyrint) plaatst. In zijn boek Christelijke symboliek en iconografie (1985) schrijft J.J.M. Timmers:

Een vreemde, nog niet geheel verklaarde verschijning in veel Franse en Italiaanse middeleeuwse kerken is het Labyrint. Dit is een gewoonlijk in de vloerbedekking of tegen de wand aangebrachte doolhof. Een van de oudste voorbeelden is te vinden in een kerk uit de 4de eeuw te Orléansville in Noord-Afrika. Hier draagt het midden van de doolhof het opschrift SANCTA ECCLESIA. Men zou hieruit kunnen afleiden, dat het de moeilijke en gevaarvolle weg tot de Kerk symboliseert. Volgens een andere opvatting zou het labyrint het beeld geweest zijn van de reis naar het $\mathrm{H}$ [eilig] Land of van de moeilijke kruisweg des Heren. De gelovigen volgden het, op hun knieën kruipend, tot in het middelpunt, waarom zij ook Chemins de Jérusalem genoemd werden. Het nog bestaande labyrint in de kathedraal van Chartres heette la lieue [vier kilometer, een uur lijkt zeer optimistisch], omdat men een uur nodig had om zijn weg op de knieën af te leggen. Voorbeelden van nog bestaande labyrinten zijn te vinden in Chartres, St.-Quentin en Bayeux, en in Italië te Pavia, Piacenza, Cremona, Brindisi, Lucca enz. Vele andere verdwenen. Het labyrint te Lucca draagt het volgende bijschrift: Hic quem Creticus edit Dedalus est Labyrinthus, / De quo nullus vadere quivit qui fuit intus, / Ni Theseus gratis Ariadne stramine iutus. Dit is het Labyrint, werk van de Kretenser Dedalus, waaruit niemand die er in was de uitweg kon vinden indien hij niet, als Theseus, wordt geholpen door de draad van Ariadne (Timmers, 1985:168 v).

Het labyrint-mozaïek uit de kerk van San Savino in Piacenza heeft in onze tijd zelfs een plaatsje gekregen in een roman die als postmoderne roman bij uitstek geldt: De naam van de roos van Umberto Eco. De plaats van het barok-labyrint bij Eco is allerminst toeval. Er zijn veel meer opvallende stijlovereenkomsten en wereldbeschouwelijke parallellen tussen de Barok en het Postmodernisme. De reden voor deze overeenkomsten wordt door cultuurhistorici gezocht in de geestelijke onzekerheid van de zeventiende eeuw en die van onze tijd rondom het nieuwe millennium.

De Middeleeuwen en de Barok adapteerden de voorstelling van het labyrint in de zin van het christelijk geloof. De filosoof Amos Comenius schreef zijn boek Het labyrint der wereld over de rusteloze zoektocht van 
de mens. Hij maakte daar een tekening bij waarin het labyrint een stedelijk aanzien heeft gekregen met de toren van Babel als markant bouwsel. Boethius van Bolswart maakte een kopergravure bij het boek Pia Desideria van Hermann Hugo met de titel "De christelijke ziel in het labyrint der wereld". Op de gravure is te zien hoe de christelijke ziel, gewapend met de pelgrimsstaf, haar weg vindt over de muren van het labyrint, zonder van die muurtjes af te vallen dankzij een engel die zich op een soort hemelse vuurtoren bevindt en met behulp van de draad van Ariadne de ziel naar haar hemelse bestemming geleidt. Met de identificatie van stad en labyrint plaatste de Barok de stad in een ethischreligieus kader dat tot in de twintigste eeuw, ook binnen een geseculariseerde context buitengewoon invloedrijk zou blijven. Een van de scheppers van een Barok-labyrint is de Jezuïet Athanasius Kircher (16021680). Het draagt de naam "das Kretische Labyrinth". Belangrijk voor de samenhang van Barok en Postmodernisme is de voorkeur die Kircher aan de dag legde voor optisch bedrog, spiegeleffecten en voor echoeffecten (akoestisch bedrog dus). Kircher heeft de meest interessante uitvindingen gedaan: afluisterapparatuur, mechanische muziekinstrumenten en een voorloper van de flipperkast. Wezenlijk is echter dat zijn machines niet bedoeld zijn om de goedgelovige christelijke gemeente een rad voor ogen te draaien als wel om verbanden te leggen tussen de meest uiteenlopende dingen. Hij ontwierp ook een metaforenmachine die maakte dat iemand die in een spiegel keek in plaats van zijn eigen gezicht de kop van een ezel, een os of van een wildeman zag. Kircher wil het ware gezicht van de mens onthullen door het te vervormen. Kircher noemde zijn machines "spectaculaire paradoxen". Algemeen gesproken, gaat het in de Barok om schokkende combinaties en om het leggen van verbanden. Alles ligt in alles besloten.

Kircher was ervan overtuigd dat in de Egyptische hiërogliefen alle wijsheid gecodeerd was in een minimum aan tekst. Het waren volgens hem teksten die binnen elke context opnieuw gelezen konden worden en telkens iets anders betekenden. Een en hetzelfde teken had derhalve binnen verschillende contexten verschillende betekenissen. Ondanks alle geheimen van de schepping gold voor Kircher dat er een innerlijke ordening bestond, een code die aan het universum ten grondslag lag. De schepping, Gods geheimschrift, was geordend en kon geordend worden weergegeven en beheerst in taal en teken. Onder de wereld bevond zich volgens Kircher een reusachtig labyrint waar zich de verborgen oorzaken bevonden van datgene wat bovengronds plaatsvond. 


\section{Het Postmodernisme komt naderbij}

Met de vertegenwoordiger van de Barok, deze intrigerende Athanasius Kircher, is het Postmodernisme opvallend dichterbij gekomen. In ieder geval reiken Umberto Eco en Athanasius Kircher elkaar de hand, zoals de kenners van het werk van Eco zullen hebben begrepen. Wezenlijk is voor mij op dit punt het bij Kircher en anderen in beeld komen van het verschuiven van de betekenis der tekens, het bewust leggen van verbanden tussen uiteenlopende dingen. In dit kader is Emanuele Tesauro's uit 1654 daterende II cannocchiale aristotelico ("De Aristotelische verrekijker") van belang, een werk waarin de verrekijker als instrument figureert waarmee we kunnen zien wat we anders niet zouden zien. De verrekijker fungeert precies zo als een metafoor:

De metafoor is veel vermakelijker dan de vergelijking. Want is het niet veel verrassender en aangenamer om als door een perspectivische buis veel objekten tegelijk te zien dan wanneer ze één voor één langs je ogen voorbijtrekken? [Citaat uit Tesauro's werk.]

Tussen de Barok en het Postmodernisme bestaat een duidelijk verband. Maar dat verband impliceert uiteraard nog geen identiteit. Wanneer we de meest radicale positie van het Postmodernisme schetsen, dan is het die van het poststructuralistisch deconstructionisme. Betekenis is onmogelijk geworden, doordat de referentialiteit van de tekens verdwenen is. Tekens kunnen alleen maar andere tekens reproduceren in een oneindige tekstualiteit. Het gaat hierbij om de oneindige semiosis. Het interpreteren van een teken zet aan tot een ander teken dat zelf weer een teken is dat aanzet tot een ander teken enzovoort. Het teken kan alleen door andere tekens worden geïnterpreteerd. De grenzen van de interpretatie worden bepaald door de context.

Tegenover deze eindeloze semiosis staat de gedachte dat er toch iets van de traditie bewaard lijkt te blijven. Het symbool als groot verband kan getransformeerd worden tot "little narrative", zoals Brian McHale het in 1992 formuleerde (McHale, 1992:24) Verlies van het centrum in de zin van Umberto Eco schaft dus niet op een absolutistische manier alle systemen af. Het staat juist meerdere structuren toe, maar wel onder het voorbehoud dat we de fictionele status van deze structuren erkennen en dat we ze niet verheffen tot de absolute, onwrikbare waarheid.

De traditie kan als tijdelijk model dienen, een model waarop wij onze hypothesen baseren. De gedachten van Umberto Eco zijn uitstekend samengevat in: Elisabeth Tonnard's, De papieren geschiedenis. Het literaire werk van Umberto Eco bekeken in het licht van de postmodernistische visie op de geschiedenis (1996). Reflectie op het verleden is een algemene tendens binnen het Postmodernisme. Binnen deze reflectie is 
volgens Tonnard - in het voetspoor van Hayden White - het verleden een papieren geschiedenis, omdat alleen door teksten betekenis wordt verleend aan het verleden (en aan het heden?). In de pluralistische werkelijkheid hebben verschillende werelden, ook de werelden die ons vooraf zijn gegaan, een plaats. Hoe wordt het labyrint, die centrale tekst uit duizenden jaren verleden, nu gebruikt? Is het labyrint een van de mogelijke "kleine verhalen"? Daar lijkt het een te pretentieus symbool voor te zijn. Wordt het labyrint in onze tijd dan ironisch opgewaardeerd? Is het een tijdelijk model waarmee de wereld temporeel beheersbaar is? Wanneer we reflecteren op het labyrint als tekst van ons bestaan, halen we het dan even terug in de sfeer van de waarheid om het vervolgens weer te verlaten?

\section{Het labyrint en de vervlietende betekenis}

Het labyrint lijkt meerdere functies te vervullen. Het is een eerste beeld voor de ervaring van de vervlietende betekenis. Het labyrint functioneert als een wereld zonder fundament, als een oneindig interpreteerbare wereld. In deze lijn wordt het opgevolgd door het begrip rizoom. De encyclopedie, in de zin van Eco is, in tegenstelling tot het woordenboek, een rizoom, zoals Deleuze en Guattari het bedoelen. Een rizoom is een netwerk van wortels. Het is naar alle kanten open en heeft geen binnenen geen buitenkant. Het rizoom is veranderbaar en elk punt kan met elk ander punt verbonden worden. Deleuze en Guattari vergelijken het klassieke boek als imitatie van de wereld met het systeem der kleine wortels, het rizoom-type. Curieus genoeg noemen zij Amsterdam de rizoom-stad waar nuttigheid met de grootste waanzin zou worden verbonden (Deleuze \& Guattari, 1977:26).

\section{Het labyrint als "klein verhaal"}

In de tweede plaats is het labyrint een "klein verhaal" waardoor zin op beperkte schaal mogelijk is. Het labyrint als idee van de geschiedenis gaat uit van de geschiedenis als proces met een aan dat proces inherente orde. Het labyrint kan derhalve als een hanteerbaar beeld van een complexe ontwikkeling worden beschouwd. Umberto Eco in 1990: "Texts are the human way to reduce the world to a manageable format" (Eco, 1990:21). Hoe functioneert Eco's roman De naam van de roos in dit verband? In De naam van de roos vergezelt de novice Adson zijn leermeester William van Baskerville, een Engelse Franciscaner monnik, naar de abdij ter voorbereiding van een ontmoeting tussen pauselijke gezanten en een delegatie Franciscanen. De abt verzet zich tegen de door het vooruitgangsgeloof gedomineerde nieuwe tijd door de wijsheid der in de bibliotheek verzamelde teksten te verdedigen. De teksten zijn 
opgeborgen in de bibliotheek, een labyrint, waarvan alleen de bibliothecaris het geheim bezit. Het boek dat de blinde (naar het beeld van de Argentijnse schrijver Borges gemodelleerde) bibliothecaris Jorge verborgen wil houden, is het tweede deel van Aristoteles' poëtica, handelend over de komedie, over de lach. Het geeft een ander beeld van de waarheid en is daarom volgens Jorge een gevaar voor de bestaande orde. De bibliotheek van Jorge is een woordenboek en geen encyclopedie. Een woordenboek is een eindige verzameling. Je zou kunnen stellen dat de bibliotheek een intertekstuele ruimte is, een rizoom zonder grenzen waarvan het labyrint slechts een zwakke afspiegeling is. Tonnard geeft de volgende analyse:

Doordat het labyrint een kunstmatige ordening vormt, waarvan we kunnen reconstrueren op welke manier de maker [bij Eco] heeft gedacht, is het mogelijk om door waarnemingen van buitenaf voorspellingen te doen over de aard, het binnenste van de bibliotheek. Bij dit soort labyrinten is het dus mogelijk om een positie in te nemen buiten de wanorde die in werkelijkheid een tot in het uiterste doorgevoerde orde is en kan vanuit die positie het geheel worden overzien (Tonnard, 1996:73).

De bibliotheek is daarom één van de creaties die nooit de totale rizomatische wereld kunnen omvatten. De vooronderstelling van dit manco van de bibliotheek is uiteraard die van het rizoom in zijn onuitputtelijke vertakkingen. Vanzelfsprekend is deze tekst van Eco - II nome della rosa - zelf een bibliotheek en dat geldt ook voor zijn andere teksten. Eco's verontrustende ironie leidt niet tot een vaste richtlijn, een draad van Ariadne, waarmee we het rizoom van de tekst kunnen lezen. We blijven ons voortdurend afvragen, wat ironie is en wat niet. We kunnen de tekst niet tot één geschiedenis reduceren. De tekst blijft een "storehouse", een "draaikolk", een "spiegelpaleis" van alternatieven en tegen-alternatieven, van verhalen en tegen-verhalen.

\section{Het labyrint als "groot verhaal"}

Ten derde kan het labyrint uitgroeien tot een volwaardig, groot verhaal dat niet onmiddellijk ter discussie wordt gesteld. Voor Helmut Jaskolski in Das Labyrinth (1994) is het de menselijke verantwoording om het hier en nu die in het middelpunt komt te staan. Hij doet een ethisch appel op een inspirerende openbaring en op de ontvanger van die openbaring. Jacques Attali (1996) verandert in zijn verhandeling over de weg der wijsheid de "chemin de Jérusalem" in de "chemin de sagesse". Attali geeft een beeld van het onderbewuste van de mens als monster in het labyrint. De dromen zijn voor hem als verboden "dédales". Het onderbewuste wordt als een oorspronkelijke gesteldheid van de geest gezien. 
Attali gaat zelfs zover om de gehele literatuur, alle vermaak, van de mythe tot de roman, als een tocht te beschouwen naar iets absoluuts, een tocht via een "parcours d'obstacles labyrinthique". De moderne mens is volgens Attali bezig om een virtuele nomade te worden. Hij vat deze combinatie van constatering en wensdroom samen in de zin: "Comprendre le labyrinthe deviendra bientôt essentiel à la maîtrise de la modernité" (Attali, 1996: 30). De terminologie van Attali is niet altijd even helder en eenduidig. Dat geldt ook voor zijn gedachten over de toekomst. Ik vertaal enkele kernzinnen uit zijn boek:

Het derde millennium zal mystiek zijn, omdat het nomadisch zal zijn. In zijn/haar eenzaamheid zal ieder wezen als een draad van een weefsel zijn, het woord van een tekst, de cel van een levend organisme, een puntje van een labyrint dat hem/haar aan de wereld bindt en transcendeert. ledereen zal een deeltje van de God zijn die zij/hij met zich meedraagt (Attali, 1996:222).

Over het doel van het nomadische bestaan zegt Attali, wederom in mijn vertaling:

Aan de uitgang van alle labyrinten zal de mens slechts andere labyrinten vinden. Sommigen hopen God daar te ontmoeten, anderen de waarheid. Anderen tenslotte een raadselachtige en broze weg tot wijsheid (Attali, 1996:223).

\section{Michael Ende en het oneindige verhaal}

Is in de literatuur al iets zichtbaar geworden van die broze weg tot wijsheid? Met zijn roman Die unendliche Geschichte (1979) heeft de Duitse schrijver Michael Ende een poging gedaan om meerdere letterkundige tradities met elkaar te verbinden en de scheiding tussen verschillende systemen binnen de letterkunde te doorbreken. Die unendliche Geschichte bezit een veelheid aan sprookjesmotieven die verband houden met het uitvoeren van opdrachten en het toegang verkrijgen tot al of niet bewaakte gesloten ruimten. Deze roman is ook een eigentijdse voortzetting van het motief van het labyrint. Bovendien zijn in het verhaal van Atréjoe en Bastiaan psychologische inzichten verwerkt die de roman voor een uitleg op grond van de gedachten van Jung uitermate geschikt maken.

In het eerste gedeelte van Het oneindige verhaal (Nederlandse vertaling uit 1982) is Atréjoe de centrale persoon, de held die het bedreigde land Fantasië moet redden. Om zijn verlossende taak te kunnen uitvoeren moet Atréjoe het zogenaamde Zuidelijk Orakel zien te bereiken. Daartoe moet hij drie poorten passeren. De eerste poort is de Grote Raadselpoort. Deze poort staat altijd open en toch is het onmogelijk om er naar 
binnen te gaan. De poort wordt bewaakt door twee sfinxen. De enige mogelijkheid om door de poort naar binnen te gaan is gegeven op het moment dat de twee sfinxen de ogen sluiten. Een helper verklaart aan Atréjoe waarom:

'De blik van een sfinx is iets totaal anders dan de blik van elk ander wezen. Jij en ik en alle anderen nemen met onze blik iets waar. Wij zien de wereld. Maar een sfinx ziet niks, die is in zekere zin blind. In plaats daarvan zenden zijn ogen iets uit. En wat is het dat zijn blik uitzendt? Alle raadsels van de wereld. Daarom kijken die twee sfinxen elkaar voortdurend aan. Want alleen een andere sfinx kan de blik van een sfinx verdragen. En stel je nu eens voor wat er gebeurt met iemand die zomaar het risico neemt het blikveld van allebei de sfinxen te doorkruisen! Hij verstijft ter plaatse en kan zich niet meer bewegen voor hij alle raadsels van de wereld heeft opgelost' (Ende, 1982:83 v.).

Niettemin ontsluieren ook Atréjou en Bastiaan de raadselen van de wereld, niet door op te lossen, maar door de onbegrijpelijke produkten van de fantasie te respecteren.

Zoals gesuggereerd, vormt Het oneindige verhaal een indrukwekkende intertekstuele en interkulturele eenheid. De vertelinstantie wordt gethematiseerd, ja de roman geeft commentaar op zichzelf, zodat er sprake is van verwantschap met modernistische en postmodernistische verteltechnieken. Deze zijn echter ten nauwste verbonden met de drie voorstellingen die ik als een belangrijke lijn in de ontwikkeling van de Europese kunst heb trachten te identificeren: de voorstelling van het leven als weg, het beeld van de omsloten, geheime tuin en dat van het labyrint. Ende's boek heeft een duidelijke verwantschap met vraagstellingen van schrijvers als Borges en Eco. Zoals Helmut Jaskolski in zijn boek Das Labyrinth aantoont, komt William van Baskerville in Eco's De naam van de roos tot de conclusie dat de mens de waarheid niet bemachtigen kan. Zijn kritische zoektocht naar de waarheid strandt op de chaotische werkelijkheid. De speurzin van de detective is niet opgewassen tegen de labyrintische vervlechtingen der tekens. De wereld als geheel is een tuin met paden die zich steeds opnieuw vertakken en verschillende kanten opgaan. Het is een netwerk dat door Jaskolski eveneens als rizoom wordt aangeduid, een wirwar van knollen en knopen. Het verwondert niet dat Jaskolski naar Kafka als auteur van het labyrint in de geschetste zin verwijst. De tocht die Jaskolski door de cultuurgeschiedenis van het labyrint maakt, wordt in de twintigste eeuw op een onverhuld pessimistische toon besloten. Het labyrint is het alomvattende symbool van onze sociale en politieke wereld geworden. Het virtuoze spel van Umberto Eco in De naam van de roos is niets anders 
dan uitstel van executie, de executie van de hoop op waarheid en verlossing. Jaskolski eindigt zijn boek niettemin met een perspectief op de toekomst. Hij formuleert dat perspectief in de vorm van een vraag en een hartstochtelijke therapeutische oproep:

\begin{abstract}
Was aber wäre Theseus ohne Ariadne gewesen? Und was ist lkaros ohne die hilfreiche Göttin, ohne die menschliche Aphrodite? Nicht die abstrakten Appelle an die Vernunft, nicht die sich wiederholende Mahnung an moralische Verpflichtungen benötigt Ikaros, sondern die Kraft des Eros, die Schwingen der Liebe, die ihn nicht ins Unendliche tragen, sondern in die Verantwortung für das Hier und Jetzt und die Zukunft. Ariadne, Aphrodite, Göttin der Liebe und des Lebens, manifestiere dich aufs neue! (Jaskolski, 1994:186 v.).
\end{abstract}

Michael Ende komt in Jaskolski's boek helaas niet voor. Daarmee is een auteur buiten beschouwing gelaten die als geen andere schrijver van deze tijd zoveel labyrinten in zijn werk heeft gepresenteerd, niet alleen in zijn Het oneindige verhaal maar zeer prominent ook in zijn verhalenbundel Das Gefängnis der Freiheit, niet slechts in woorden maar als tekenaar ook in beelden. Afwijkend van de algemene trend is Ende zonder twijfel in zijn pogingen om het labyrint op te nemen in een groter geheel waarin de mens naast het labyrint ook de tuin kent. En deze tuin is als paradijselijk oord van vrede en gerechtigheid het uiteindelijke doel. Jammer genoeg is Ende het slachtoffer geworden van het verlangen der critici om zijn werk zodanig te rubriceren dat het zijn appel goeddeels verloor en als jeugdliteratuur in een ongevaarlijke hoek terechtkwam. De valse kroon op deze ontwikkeling was de verfilming van de roman onder de titel The neverending story die met de essentie van het boek niets meer te maken heeft. Dankzij Michael Ende is het motief van de geheime tuin echter levend gebleven en kan het zijn heilzame functie ook verder vervullen.

De studie van Jacques Attali biedt nog weer een ander perspectief op de culturele ontwikkeling waarbij de voorstelling van het labyrint een leidende rol speelt. Attali's boek heeft net als dat van Jaskolski een therapeutische basis. Het labyrint vraagt blijkbaar om een oplossing. Atali's boek richt zich tegen een ontwikkeling die vooral met de Verlichting wordt geassocieerd, namelijk die van het denken met behulp van de rechte lijn in plaats van de dolende beweging. De kern van zijn Jungiaanse opvatting is dat een bepaalde laag van de menselijke ziel gemeenschappelijk bezit is van alle mensen. Tot dat gemeenschappelijke bezit behoort de voorstelling van het leven als reis, als tocht door het labyrint. Deze voorstelling is echter sedert enkele eeuwen, vanaf de Verlichting, geneutraliseerd tot een ornament, een versiering van het beeld van de tuin. In de huidige cultuur, van de computerspelletjes tot World Wide 
Web zien we de oude patronen weer terugkeren. De vraag naar de geestelijke effecten van deze oude vormen in een nieuw (computertechnologisch) jasje blijft ook na Attali's studie recht overeind.

\section{Conclusie}

Het labyrint als voorstelling is zowel de bevestiging van de eindeloze verschuiving van betekenis als de opheffing (of poging tot opheffing) daarvan. Blijkbaar is de gedachte van het dwalen en zoeken naar uitgang en verlossing niet los te maken van de voorstelling dat voor die verlossing hulp nodig is. Bij Jaskolski is de hulp afkomstig van een andere ethiek, de ethiek van de verantwoordelijkheid. Bij Attali komt de hulp tot stand doordat de mens een wezenlijk apriori van zijn denken verlaat. Daarbij moet de vraag gesteld worden of het labyrint na het omineuze en toch normaal zich gedragende jaar 2000 een speels, klein verhaal zal blijven of wellicht pluralistisch uitwaaierend een kernachtig groot verhaal zal worden waarin elementaire lijnen van de traditie op verplichtende wijze zijn opgenomen. De labyrinten in het landschap lijken een indicatie in de richting van het grote verhaal te zijn. Maar of de Middeleeuwen ooit op een eigentijdse wijze zullen terugkeren, is zeer twijfelachtig. Bij de Barok zullen de herontdekkingen de komende jaren niet van de lucht zijn.

\section{Bibliografie}

Attali, Jacques. 1996. Chemins de sagesse. Traité du labyrinthe. Parijs : Fayard.

Bunyan, John. 1984. The pilgrim's progress from this world to that which is to come. Edited with an introduction by N.H. Keeble. Oxford : Oxford University Press. (The World's Classics.)

Deleuze, Gilles \& Guattari, Félix. 1977. Rhizom. Berlijn : Merve Verlag. [Oorspronkelijke uitgave: Rhizome. Introduction. Parijs. Les Editions de Minuit, 1976.]

Eco, Umberto. 1997. De naam van de roos \& Naschrift [oorspronkelijk: II nome della rosa, Postille a 'Il nome della rosa'. Milaan. Gruppo Editoriale Fabbri, Bompiani, Sonzogno, Etas S.p.A., 1980.] Achtendertigste druk. Amsterdam : Bert Bakker.

Eco, Umberto. 1990. The limits of interpretation. Bloomington/Indianapolis : Indiana University Press.

Ende, Michael. 1982. Het oneindige verhaal. [Oorspronkelijk Die unendliche Geschichte. Stuttgart. K. Thienemanns Verlag, 1979.] Alphen aan den Rijn : Sijthoff.

Ester, Hans. 1996. Geheime tuinen en gesloten deuren. Over open en verboden ruimtes in tekst en beeld. In: In: Mulder, Etty \& Ester, Hans (red.) De schone waarheid en de steen der dwazen. Transartistieke studies. Baarn : AMBO. p. 167179.

Jaskolski, Helmut. 1994. Das Labyrinth. Symbol für Angst, Wiedergeburt und Befreiung. Stuttgart : Kreuz Verlag.

Kern, Hermann. 1999 [1982]. Labyrinthe. Erscheinungsformen und Deutungen. 5000 Jahre Gegenwart eines Urbilds. Vierde, onveranderde druk. München : Prestel Verlag. 
McHale, Brian. 1992. Constructing Postmodernism. Londen/New York : Routledge.

Mascaro, Maria-Pia. 1998. Retrouver son âme là-bas, en suivant les méandres du labyrinthe. Le Temps (Genève), juni 16.

Teichert, Wolfgang. 1986. Gärten. Paradiesische Kulturen. Stuttgart : Kreuz Verlag. (Buchreihe Symbole.)

Tesauro, Emanuele. 1654. II cannocchiale aristotelico.

Timmers, J.J.M. 1985. Christelijke symboliek en iconografie. Vijfde druk. Weesp : De Haan.

Tonnard, Elisabeth. 1996. De papieren geschiedenis. Het literaire werk van Umberto Eco bekeken in het licht van de postmodernistische visie op de geschiedenis. Nijmegen : Instituut voor Algemene Literatuurwetenschap. (Ongepubliceerde doctoraalscriptie.)

Tworuschka, Udo. 1991. Sucher. Pilger. Himmelsstürmer. Reisen im Diesseits und Jenseits. Stuttgart : Kreuz Verlag. (Buchreihe Symbole.)

\section{Kernbegrippe:}

besloten tuin

draad van Ariadne, de

doolhof

labyrint als symbool; connotaties

levensweg

literaire motief van het labyrint, het

paradijs; als einddoel van het levensreis

tuin en labyrint

\section{Key concepts:}

Ariadne's clue

enclosed garden

garden and labyrinth

labyrinth

labyrinth as symbol; connotations

literary motif of the labyrinth

paradise as end goal of the path of life

path of life, the 